\title{
Status of organochlorine pesticides in Ganga river basin: anthropogenic or glacial?
}

\author{
P. K. Mutiyar and A. K. Mittal \\ Department of Civil Engineering, Indian Institute of Technology Delhi, 110016 New Delhi, India \\ Correspondence to: A. K. Mittal (akmittal@civil.iitd.ac.in)
}

Received: 27 December 2011 - Published in Drink. Water Eng. Sci. Discuss.: 30 January 2012

Revised: 27 March 2013 - Accepted: 26 June 2013 - Published: 4 July 2013

\begin{abstract}
This study reports the occurrences of organochlorine pesticides (OCPs) in the Ganga river basin covering 3 states, i.e., Uttarakhand, Uttar Pradesh and Bihar comprising $72 \%$ of total river stretch consisting of 82 sampling points covered through 3 sampling campaigns. Samples were monitored for 16 major OCPs, including hexachlorocyclohexanes (HCHs), Endosulfan group, Aldrin group, DDTs and Heptachlor group pesticides.

The results showed the $\mathrm{nL}^{-1}$ levels contamination of OCPs in all the stretches sampled during these campaigns. The results also revealed that different types of OCPs were dominating in different stretches in accordance with the land use practices and agricultural runoff generated from those stretches. HCHs were most frequently detected (detection rate $=75 \%$ ) in mountainous stretch; Endosulfans were prominent in UP (detection rate $=75 \%$ ) stretch while in BR stretch Aldrin group pesticides were paramount (detection rate $=34 \%$ ). Source apportionment of the OCP's revealed that in the upper reaches of the Ganges i.e., in the state of Uttarakhand, the glacial melt may be responsible for the presence of OCP's. In the lower reaches, intensive agriculture and industrial activities may be significantly contributing these pesticides. The samples from tributaries of Ganga river were found to contain higher numbers of pesticides as well as higher concentrations. The maximum total pesticide concentration in an individual sample during these sampling campaigns was found in the Son river sample $\left(0.17 \mu \mathrm{gL}^{-1}\right.$, Location: Koilwar, Bhojpur, Bihar).
\end{abstract}

\section{Introduction}

River basin management plans in India have traditionally considered the point sources of water pollution. The nonpoint sources of pollution have largely missed out. Non-point pollution sources are of greater importance than point source pollution particularly in rural catchments, where agricultural runoff is the major pollution contributor, which brings nutrients and pesticides to the rivers (Duda, 1993; Jain, 2002). Similar conditions of agricultural practices and runoff, exists in Ganga basin and thus non point sources of pollution to the rivers are of serious concern as mostly pesticides entering river systems via diffuse sources (Holvoet et al., 2007). Trends of high levels of pesticide residues in agricultural runoff leading to river contamination have been reported from different parts of the world (Schulz, 2001a, b;
Varca, 2012; Oliver et al., 2011). In the Ganga river basin, where agriculture predominate the land use activities, pesticides used in agriculture could easily find their way into the river via runoff. Organochlorine pesticides (OCPs) have been extensively used in India for agricultural and public health purposes. OCPs in different environmental matrices are a matter of concern as the complete environmental fate of these chemicals is still an unexplored field.

The Indo-Gangetic alluvium plain, due to fertile soils, is the region of high agriculture and industrial activities with high population density, where pesticides may enter the water environment through runoff. As the OCPs are persistent in nature and could easily find their way in runoff after several years of their application (Kreuger, 1998). So, even after the recent ban on the use of these pesticides, monitoring of their residues in the rivers is required to assess the 
Table 1. Various river stretches and the major rivers covered during the sampling campaigns.

\begin{tabular}{llll}
\hline Stretches & Utrakhand (UK) & Uttar Pradesh (UP) & Bihar (BR) \\
\hline Sampling months & Dec 2010-Jan 2011 & Jun-Jul 2011 & Jul-Aug 2011 \\
Distance (km) & 193 & 1131 & 341 \\
1st Sampling Point & Rudraprayag & Bijnor & Chhapra \\
Last Sampling Point & Haridwar & Ballia & Kohalgaon \\
No of sampling points & 20 & 36 & 26 \\
Major rivers covered during & Mandakini, Alaknanda, & Ramganga, Ghaghra, Yamuna, & Son, Gandak, Ganga \\
sampling campaign & Bhagirathi, Ganga & Varuna, Gomti, Rapti, Aami, Ganga & \\
\hline
\end{tabular}

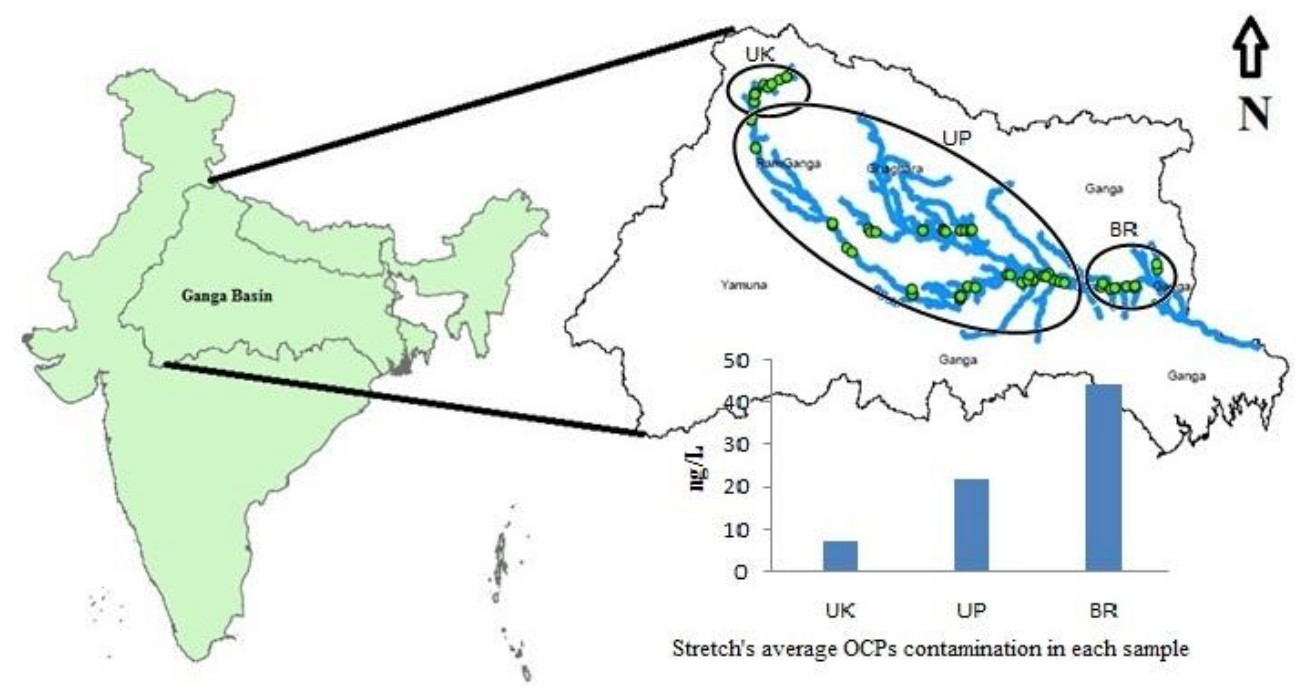

Figure 1. Sampling location of the river Ganga.

impact on human health and related ecological risks. Previously reported OCPs levels in river Ganga are either for specific tributaries or for a stretch of the river. There is no single study available reporting the levels of these contaminants across the Ganga basin. Source apportionment of OCPs in Ganga river is also of high importance. It is yet to be established whether glacial sources or anthropogenic activities contribute pesticides to various rivers of Ganga basin. Glacial melt could be another source of pesticide contamination in the Ganga basin as glacial melt contributes the major share of the Ganga and its tributaries. Rivers in the Ganga basin are the main source of freshwater for half the population of India and Bangladesh. Thus, an understanding of the fate of OCPs in Ganga basin rivers, and identification of their sources of origin is warranted. The present study reports the status of OCPs in the Ganga river and its major tributaries passing through three different states in India. The study area covers a $1805 \mathrm{~km}$ long stretch of river Ganges, covering $72 \%$ of its entire length. Sampling campaigns were carried out in three states, i.e., Uttarakhand (UK), Uttar Pradesh (UP) and Bihar (BR), which represent a major part of the Ganga basin.

\section{Materials and methods}

\subsection{Study area}

The Ganga rises at $7010 \mathrm{~m}$ in Gangotri, Uttarakhand, India, on the southern slopes of the Himalayan range. It flows through five different states, Uttarakhand (UK), Uttar Pradesh (UP), Bihar (BR), Jharkhand (JK) and West Bengal (WB) covering a distance of $2525 \mathrm{~km}$ before it enters the Bay of Bengal. Ganga river and its major tributaries at Uttarakhand (UK), Uttar Pradesh (UP) and Bihar (BR) states represent the study area. The river Ganga was sub-divided into three stretches representing different watershed conditions as the UK, UP and BR stretch. The stretches were divided considering (1) different types of watershed, land-use activities, flow types and (2) state boundaries since states are responsible for managing the discharges to the river. The division of river stretches on the basis of states will help in understanding the health of the river in that particular state and their environmental awareness. Details on the sampling campaigns undertaken are presented in Table 1. Water samples were picked from 82 different points during these sampling campaigns from 3 different stretches/regions. The locations of the sampling points are shown in Fig. 1, while Fig. 2 


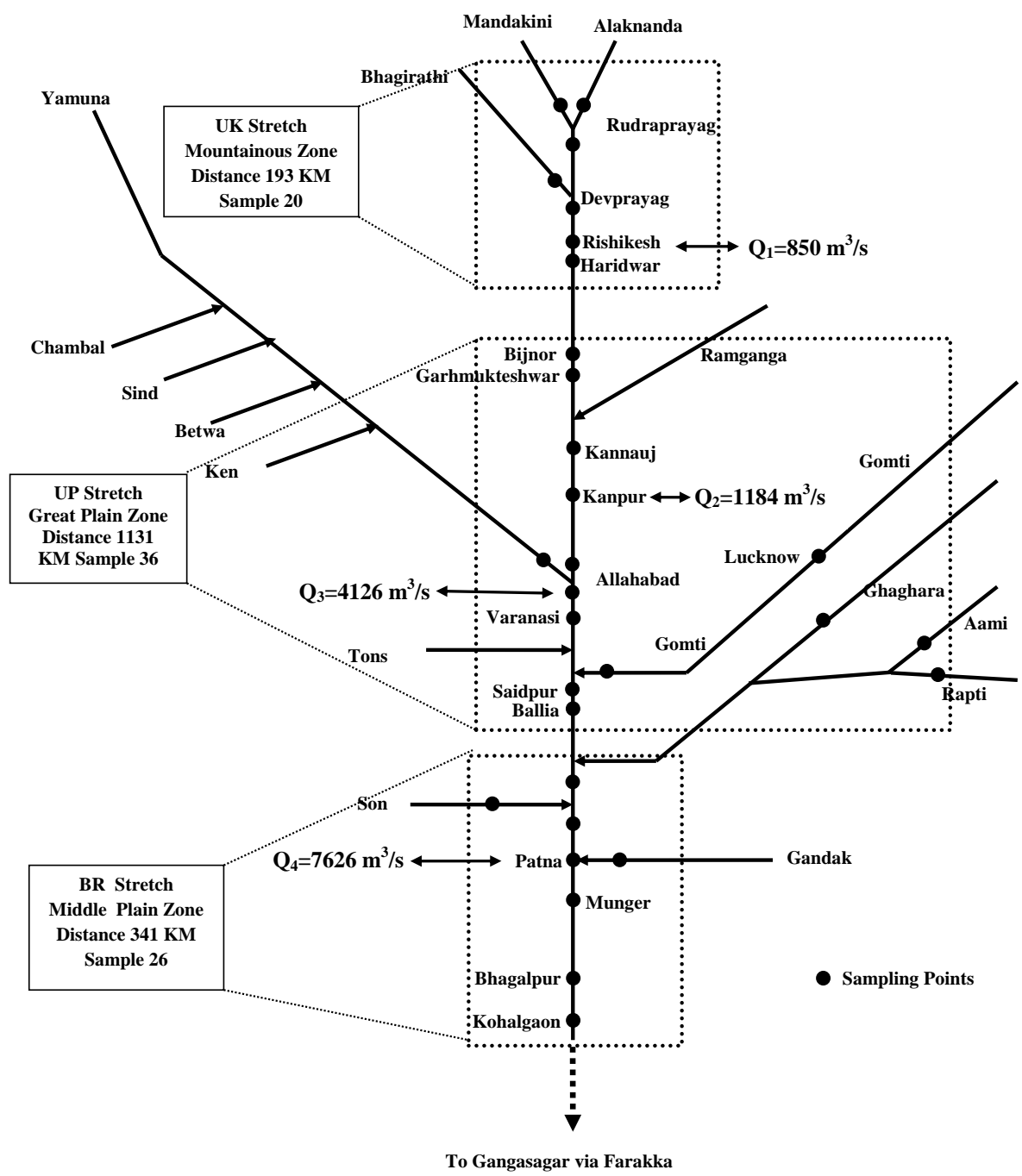

Figure 2. Sampling locations and space boundary of each sampling campaign along river Ganga (flow data were of CWC, Delhi taken from NGBRA, 2011 report as cross reference).

showed the sampling points and a flowchart of the rivers covered during each sampling campaign. The UK stretch was the smallest stretch, while UP stretch was the longest stretch of the sampling campaigns.

\subsubsection{UK stretch}

The State of Uttarakhand (UK) has three districts which fall in the mainstream of Ganga: Haridwar, Tehri Garhwal and Uttarkashi. Sampling campaigns of this stretch was carried out in December 2010. Sampling was started from upstream of Rudraprayag at Alaknanda and Mandakini rivers, and it went up to downstream of Haridwar (Table 1). This area is the hilly-mountainous zone of the river Ganga with a high bed slope (1:67) and mean flow rate of $856 \mathrm{~m}^{3} \mathrm{~s}^{-1}$ (Fig. 2). Domestic sewage is the major source of pollution since there are no other major agricultural or industrial activities in this stretch.

\subsubsection{UP stretch}

It is the mid-stretch of the river and forms a part of the Great Plains of Ganga basin. It constitutes 17 districts of Uttar Pradesh (UP). Sampling campaign was carried out in June and July 2011. Sampling started from upstream of Bijnor and went up to downstream of Ballia, separating a distance of $1131 \mathrm{~km}$ (Fig. 2). Samples from Ramganga, Ghaghra, Yamuna, Gomti, Rapti and Aami; the major tributaries of Ganga, were also taken, to quantify the pesticide contamination contributed by the tributaries of river Ganges. Total 36 samples were taken from this stretch (Table 1). Rivers, in this stretch, receive pollution from highly diversified sources, including domestic, industrial and agricultural sources. Downstream to Haridwar, where the Ganga opens to the Gangetic Plains, major share of water is diverted by various barrages for irrigation and other purposes. The Ganga does not receive any major tributary until its tributary, Ramganga river joins 
at Kannauj, which is $460 \mathrm{~km}$ downstream from Haridwar (Fig. 2). River has relatively less flow upto Allahabad, where the Yamuna confluences the river Ganges. Downstream to Allahabad, river is joined by Tons and Gomti (Fig. 2). The subsequent upper plain section extends from Rishikesh to Allahabad at a slope of one in 4100 and a mean flow rate range between $850-1720 \mathrm{~m}^{3} \mathrm{~s}^{-1}$ before its confluence with the Yamuna.

\subsubsection{BR Stretch}

There are 12 districts which fall within the Ganga basin in Bihar (BR), where agriculture and commercial fisheries in the river are the two most important source of livelihood for people. The river Ganga receives several major tributaries in this section, namely, Ghaghara, Son, Gandak, and Kosi. The flow in this stretch continually increases since major tributaries confluence to the Ganga river in this stretch. The average annual flow increased to $7626 \mathrm{~m}^{3} \mathrm{~s}^{-1}$ at Patna (Fig. 2) from $4126 \mathrm{~m}^{3} \mathrm{~s}^{-1}$ at downstream of Allahabad. The sampling campaign was carried up to Kohalgaon, just a few $\mathrm{km}$ before joining Kosi. The sampling campaign covered $341 \mathrm{~km}$ stretch (Fig. 2) of the river Ganges, from Chhapra to Kohalgaon, via Patna, Munger and Bhagalpur (Table 1). The samples were also collected from the Son and Gandak river, the major tributaries of Ganga in this stretch. This river stretch receives pollution from domestic, agricultural as well as industrial sectors. Raw sewage flows into the river in this stretch since sewage is not treated in $\mathrm{Bi}$ har due to various reasons as reported (CPCB report, 2009) (http://www.cpcb.nic.in/newitems/8.pdf).

\subsection{Water sampling, collection and storage}

During these sampling campaigns, which were carried out between December 2010 and August 2011, a total of 82 water samples were collected from different sites (Figs. 1 and 2). Two samples were taken from each site during each sampling campaign. One sample was collected in a $1000 \mathrm{~mL}$ HDPE bottles, was used to determine physico-chemical parameters and OCP analysis, while the second sample was taken in $100 \mathrm{~mL}$ HDPE bottle and preserved with acid. This acidified sample was used for TOC, $\mathrm{NO}_{3}^{-}-\mathrm{N}$ and $\mathrm{NH}_{4}^{+}-\mathrm{N}$ analysis. Sampling bottles were rinsed with river water and were carefully filled to overflowing, without trapping air bubbles in sealed bottles. The samples were transported in cool-box with ice packs and subsequently stored in a refrigerator at $4{ }^{\circ} \mathrm{C}$ until further analysis. All the samples were transported on ice and kept under refrigeration until performance of laboratory analysis.

\subsection{Reagents and standards}

Analytical grade (AR) chemicals (Merck, Germany) were used throughout the study without any further purification.
Reagents and calibration standards for physico-chemical analysis were prepared using double glass distilled water. The glass-wares were washed with dilute nitric acid $(1.15 \mathrm{~N})$ followed by several portions of distilled water. EPA 502 Pesticide Standard Mix (49690-U) was procured from SigmaAldrich USA. The working standards of pesticides were prepared by diluting EPA pesticide mixture standard in $n$ Hexane and were stored at $-20^{\circ} \mathrm{C}$. The samples were analysed within one week of sampling campaigns.

\subsection{Physico-chemical parameters}

Samples were analysed for different physico-chemical parameters: $\mathrm{pH}$, electrical conductivity (EC), alkalinity, chloride, hardness, dissolved oxygen (DO), total organic carbon (TOC), nitrate, and ammonia as per APHA (1998). EC, pH, DO and total dissolved solids (TDS) were measured onsite using portable meters. Alkalinity, chloride and hardness were measured by titration method in the laboratory. Nitrate and ammonia were measured by selective ion electrode (Thermo and $\mathrm{HACH}$, respectively), while TOC was analysed on TOC analyser (Shimadzu).

\subsection{Extraction}

The method prescribed by APHA (1998) with some modifications was used for the extraction of OCP residues from the water samples. A liquid liquid extraction (LLE) method, using $n$-hexane as solvent, was used for extraction of pesticide residues. Samples were prefiltered using $0.45 \mu \mathrm{m}$ glass fiber filter to remove suspended impurity and were extracted without any $\mathrm{pH}$ adjustment. Sample containers were shaken and each $500 \mathrm{~mL}$ portion of filtered sample was transferred to a separating funnel ( $1000 \mathrm{~mL}$ cap.) fitted with glass-stopper. It was mixed with $30 \mathrm{~g}$ of $\mathrm{NaCl}$ and $50 \mathrm{~mL}$ of $n$-hexane. The sample was shacked properly for $30 \mathrm{~min}$ and the hexane layer was separated. Two further extractions with $30 \mathrm{~mL}$ $n$-hexane were done and the combined hexane extract was treated with $5 \mathrm{~g}$ anhydrous $\mathrm{Na}_{2} \mathrm{SO}_{4}$ to remove traces of water. The water-free extract was rotary vacuum evaporated to a small volume and transferred to a glass-stoppered test tube followed by evaporation of solvent under a mild stream of $\mathrm{N}_{2}$ to $0.5 \mathrm{~mL}$. The concentrated extracts were transferred to air-tight gas chromatograph (GC) vials and stored at $-20^{\circ} \mathrm{C}$ until their analysis.

\subsection{OCPs analysis}

The determination of OCPs was performed on a Thermo Trace GC Ultra gas chromatograph equipped with 63-Ni micro-electron capture detector (GC-ECD) and an autosampler. The column specifications and operating conditions are given in Table 2. Analysis was performed by EPA method 508, with slight modification. Identification of individual OCPs was based on comparison of retention 
Table 2. Operating conditions used for the operation of GC-ECD (Double column confirmation).

\begin{tabular}{lcc}
\hline & & GC-ECD \\
\hline Column & $\begin{array}{l}\text { DB-5, fused silica capillary column } \\
(30 \mathrm{~m} \times 0.25 \mathrm{~mm} \text { ID, film thickness } 0.25 \mu \mathrm{m})\end{array}$ & $\begin{array}{c}\text { DB-1701, fused silica capillary column } \\
(30 \mathrm{~m} \times 0.25 \mathrm{~mm} \text { ID, film thickness } 0.25 \mu \mathrm{m})\end{array}$ \\
\hline Purpose & Screening and Quantification & Cross confirmation by Retention Pattern \\
\hline $\begin{array}{l}\text { Injector } \\
\text { Temperature }\end{array}$ & & $250^{\circ} \mathrm{C}$ \\
\hline $\begin{array}{l}\text { Injection } \\
\text { Volume }\end{array}$ & & $2.5 \mu \mathrm{L}$ (Splitless mode) \\
\hline $\begin{array}{l}\text { Oven } \\
\text { Programming }\end{array}$ & 90 to $150^{\circ} \mathrm{C} @ 15^{\circ} \mathrm{C} \mathrm{min}^{-1}, 150$ to $220^{\circ} \mathrm{C} @ 3{ }^{\circ} \mathrm{C} \mathrm{min}^{-1}$ and 220 to $270{ }^{\circ} \mathrm{C} @ 5^{\circ} \mathrm{C} \mathrm{min}^{-1}$ \\
\hline $\begin{array}{l}\text { Detector } \\
\text { Temperature }\end{array}$ & \\
\hline Carrier gas & & $280^{\circ} \mathrm{C}$ \\
\hline Makeup gas & Helium @ $1.2 \mathrm{~mL} \mathrm{~min}^{-1}$ \\
\hline
\end{tabular}

time between samples and the standard solution by double column chromatography under similar conditions. DB$5(30 \mathrm{~m} \times 0.25 \mathrm{mmi}$.d., and $0.25 \mu \mathrm{m}$ film thickness $)$ and DB-1701 $(30 \mathrm{~m} \times 0.25 \mathrm{~mm}$ i.d., and $0.25 \mu \mathrm{m}$ film thickness $)$ columns were used in the analysis. Tentative identifications of the pesticides were made on the basis of retention time obtained using DB-5. These were subsequently confirmed with second capillary column, DB-1701, having dissimilar liquid phase with different retention properties. The injection volume, column conditions, temperature programming, injector and detector temperature were kept the same for GC-ECD in both analyses. Helium was used as the carrier gas at a constant flow of $1.2 \mathrm{~mL} \mathrm{~min}^{-1}$ and high purity nitrogen was used as make-up gas $\left(40 \mathrm{~mL} \mathrm{~min}^{-1}\right)$. Samples were injected using Thermo AS 3000 auto-sampler. Injection volume was $2.5 \mu \mathrm{L}$ in splitless mode for each sample (Table 2). The instrument was operated by Xcaliur software (Thermo Finnigan). Quality of extraction and detection procedure was ensured by spiking 5 different concentrations of each OCP standard with distilled water, and extracting by the same method. Recovery was determined. Table 3 presents recovery efficiency (RE), retention time (RT) and pattern of compounds eluting on both the columns. The DB-5 column was used for quantification, while DB-1701 was used for compound cross confirmation by retention pattern. The important physico-chemical properties of investigated OCPs are expressed elsewhere (Mutiyar et al., 2011).

\section{Result and discussion}

\subsection{Physico-chemical parameters (general water quality parameters)}

Both, the quantity and quality of water get affected as the water from the river is either being diverted for various beneficial uses (canals for irrigation, industrial and drinking purposes) or by the sewage from the cities and agricultural runoff from other areas flowing into the river. The water quality of all the three stretches covered during different sampling campaigns is shown in Table 4. Water quality in mountainous stretch (UK stretch) is very good, with high DO levels $\left(\mathrm{DO}_{\text {avg }}\left(\mathrm{mg} \mathrm{L}^{-1}\right)=7.7+0.6\right)$, very low EC, TDS and TOC, indicating no significant pollution load in this stretch. The lower organic loading from the small cities of UK and high flow in the river keeps the stretch relatively clean. In this stretch, the major class 1 cities on the Ganges are Rishikesh and Haridwar, where 3 sewage treatment plants (STPs) are in operation. The STPs reduce 61-93\% organic loadings and half of trace contaminants present in the sewage (CPCB report, 2009; Mutiyar and Mittal, 2013). Domestic sewage is the major contributor of pollution in this stretch, which is more significant towards the end of this stretch where the last sampling point is situated, i.e. Haridwar and Rishikesh. Kumar et al. (2010) reported that the water quality of UK river stretch is of category A as per CPCB river classification, except for the stretch downstream of Haridwar, the last sampling point of the campaign 1. Results revealed similar situation in this study (Table 4). The UP stretch is the longest stretch of the sampling campaign, including many rivers and the sub-basins of the Ramganga, Ghaghra and Gomti river. The total discharge of wastewater from this zone to Ganga basin is second maximum after Delhi. The water quality in 
Table 3. Standardisation of OCP's compounds using GC-ECD.

\begin{tabular}{|c|c|c|c|c|c|}
\hline Compound & $\mathrm{RT}(\min )(\mathrm{DB}-5)$ & Recovery (\%) & $R^{2}$ & MQL $\left(\mathrm{ng} \mathrm{L}^{-1}\right)$ & Retention Pattern (DB-1701) \\
\hline$\alpha-\mathrm{HCH}(\mathrm{H} 1)$ & 12.00 & 71.28 & 0.999 & 0.01 & $\alpha-\mathrm{HCH}(\mathrm{H} 1)$ \\
\hline$\beta-\mathrm{HCH}(\mathrm{H} 2)$ & 13.42 & 79.42 & 0.998 & 0.01 & $\gamma-\mathrm{HCH}(\mathrm{H} 3)$ \\
\hline$\gamma-\mathrm{HCH}(\mathrm{H} 3)$ & 14.76 & 70.99 & 0.999 & 0.01 & Heptachlor (He1) \\
\hline$\delta$-HCH (H4) & 15.02 & 78.56 & 0.999 & 0.01 & Aldrin (A1) \\
\hline Heptachlor (He1) & 16.70 & 87.53 & 0.996 & 0.01 & $\beta-\mathrm{HCH}(\mathrm{H} 2)$ \\
\hline Aldrin (A1) & 18.41 & 146.78 & 0.999 & 0.01 & $\delta$ - $\mathrm{HCH}(\mathrm{H} 4)$ \\
\hline Hepta-Epoxide (He2) & 20.56 & 59.55 & 0.999 & 0.01 & Hepta-Epoxide (He2) \\
\hline$\alpha$-Endo (E1) & 22.45 & 107.97 & 0.999 & 0.01 & $\alpha$-Endo (E1) \\
\hline 4,4'-DDE (D1) & 23.87 & 123.87 & 0.999 & 0.01 & $4,4^{\prime}-\mathrm{DDE}$ (D1) \\
\hline Dieldrin (A2) & 24.09 & 86.16 & 0.999 & 0.01 & Dieldrin (A2) \\
\hline Endrin (A3) & 25.01 & 87.70 & 0.998 & 0.01 & Endrin (A3) \\
\hline$\beta$-Endo (E2) & 25.75 & 90.85 & 0.998 & 0.01 & 4,4'-DDD (D2) \\
\hline $4,4^{\prime}-\mathrm{DDD}(\mathrm{D} 2)$ & 26.40 & 87.47 & 0.997 & 0.01 & $\beta$-Endo (E2) \\
\hline Endrin-aldehyde (A4) & 28.05 & 133.12 & 0.995 & 0.01 & 4,4’-DDT (D3) \\
\hline Endo-Sulfate (E3) & 28.44 & 85.80 & 0.995 & 0.01 & Endrin-aldehyde (A4) \\
\hline 4,4'-DDT (D3) & 31.53 & 99.22 & 0.990 & 0.01 & Endo-Sulfate (E3) \\
\hline
\end{tabular}

$\mathrm{MQL}=$ methods quantification limit

Table 4. River Water Quality of Ganga Basin covered during sampling campaigns (December 2010-August 2011).

\begin{tabular}{llll|llll|lll}
\hline & \multicolumn{3}{c}{ UK } & \multicolumn{3}{c}{ UP } & \multicolumn{3}{c}{ Bihar } \\
& Range & Avg & SD & Range & Avg & SD & Range & Avg & SD \\
\hline pH & $7.7-8.1$ & 7.9 & 0.1 & $7.2-8.6$ & 7.9 & 0.4 & $7.1-8.8$ & 8.4 & 0.4 \\
EC $\left(\mu \mathrm{sm}^{-1}\right)$ & $19.5-42.9$ & 32.2 & 7.4 & $118.8-381.0$ & 214.2 & 75.5 & $186.7-452$ & 345 & 74 \\
TOC $\left(\mathrm{mg} \mathrm{L}^{-1}\right)$ & $0.050-0.664$ & 0.261 & 0.274 & $0.1-4.6$ & 2.5 & 1.1 & $0.1-18.6$ & 2.3 & 3.5 \\
Nitrate $\left(\mathrm{mg} \mathrm{L}^{-1}\right)$ & $\mathrm{NM}$ & - & - & $0.7-2.8$ & 1.8 & 0.6 & $1.5-5.1$ & 2.9 & 0.9 \\
Ammonia $\left(\mathrm{mg} \mathrm{L}^{-1}\right)$ & $\mathrm{NM}$ & - & - & $0.5-7.9$ & 3.4 & 1.9 & $0-0.5$ & 0.1 & 0.1 \\
Chloride $\left(\mathrm{mg} \mathrm{L}^{-1}\right)$ & $20-40$ & 29.5 & 6.9 & $13.0-32.1$ & 23.3 & 4.8 & $29-149$ & 49.4 & 24 \\
Hardness $\left(\mathrm{mg} \mathrm{L}^{-1}\right)$ & $\mathrm{NM}$ & - & - & $65.2-143.2$ & 98.9 & 18.6 & $100-603$ & 190.3 & 95.5 \\
Alkalinity $\left(\mathrm{mg} \mathrm{L}^{-1}\right)$ & $50-110$ & 83.5 & 15.7 & $71.2-164.4$ & 109.4 & 21.4 & $102-401$ & 178.4 & 89.6 \\
TDS $\left(\mathrm{mg} \mathrm{L}^{-1}\right)$ & $12.5-27.5$ & 20.6 & 4.7 & $114.8-286$ & 175.9 & 40.6 & $119.5-289.3$ & 220 & 47.4 \\
DO $\left(\mathrm{mg} \mathrm{L}^{-1}\right)$ & $6.7-9.2$ & 7.7 & 0.6 & $1-6.5$ & 5.6 & 1.4 & $4.0-9.4$ & 6.9 & 1.4 \\
\hline
\end{tabular}

Avg $=$ Average, $\mathrm{SD}=$ Standard deviation, $\mathrm{NM}=$ Not measured

the stretch is affected by domestic and industrial discharges, and agricultural runoff. The DO levels in all the samples were in the range of $1-6.5 \mathrm{mg} \mathrm{L}^{-1}\left(\mathrm{DO}_{\mathrm{avg}}\left(\mathrm{mg} \mathrm{L}^{-1}\right)=6.5+1.4\right)$, however this zone has some of the worst polluted stretches, including Kanpur and Allahabad regions. But due to high monsoonal flow, the river water quality appeared good from the water quality data obtained during this sampling campaign (Table 4). The minimum DO $\left(1 \mathrm{mg} \mathrm{L}^{-1}\right)$ was reported from Varuna river, a small tributary of the Ganga, at Varanasi where this river has very less flow even during the monsoon season. The recent report on trends on water quality in the Ganga basin (CPCB, 2009) showed that river water quality of this stretch is fine except maximum biochemical oxygen demand $\left(\mathrm{BOD}_{5}\right)$ levels, in Kannauj-Gazipur segment. In Bihar, no sewage treatment plant (STP) was found working during the sampling campaigns. The total installed sewage treatment capacity is 84 mld against total discharge of $671 \mathrm{mld}$ in Ganga basin, and none of the STPs is functional in Bihar (CPCB report, 2009). Though, the sewage management in Bihar is very poor, but the water quality continually improved. It may be attributed to the dilution provided by the high flow from the major tributaries in this stretch. The DO levels were high $\left(\mathrm{DO}_{\mathrm{avg}}\left(\mathrm{mg} \mathrm{L}^{-1}\right)=6.9+1.4\right)$ and Gangatic dolphins were seen during the sampling at various places, from Patna to Kohalgaon. The water quality was good and the report on trends in water quality in the Ganga basin $(\mathrm{CPCB}$, 2009) supports the data as water quality in Bihar segment was well within permissible limits except for fecal coliforms (FC).

\subsection{Organochlorine pesticides}

Various types of pesticides are widely used in agricultural sector all over the Ganga basin and have been frequently 


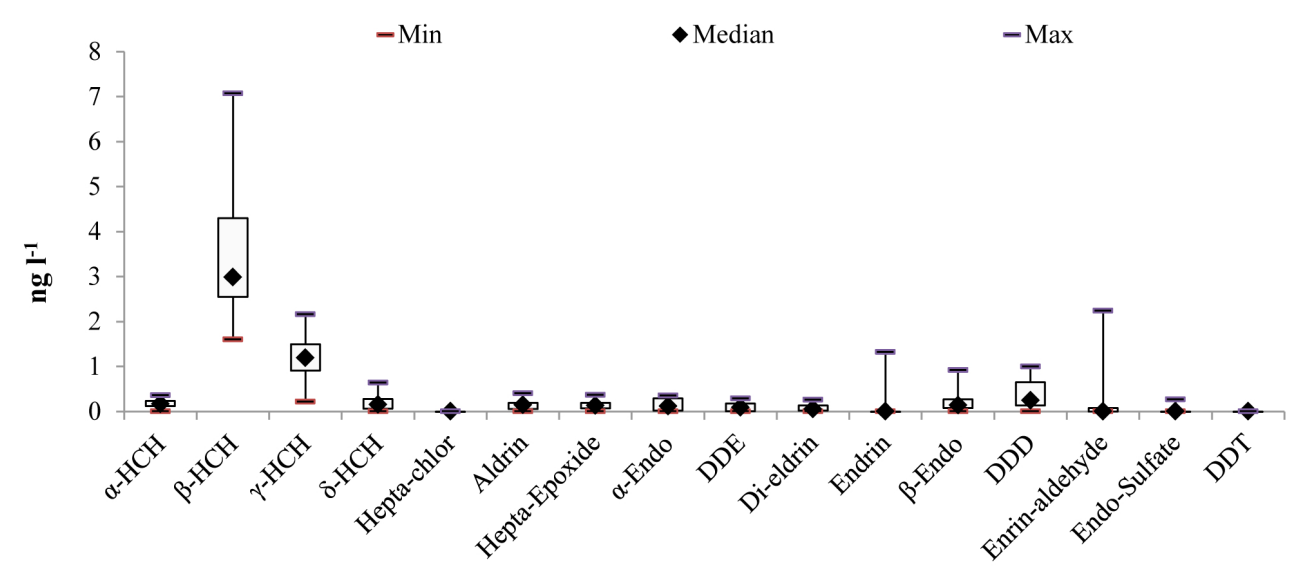

Figure 3. Organochlorine pesticide residues $\left(\mathrm{ng} \mathrm{L}^{-1}\right)$ in river water samples of Uttarakhand (UK) area.

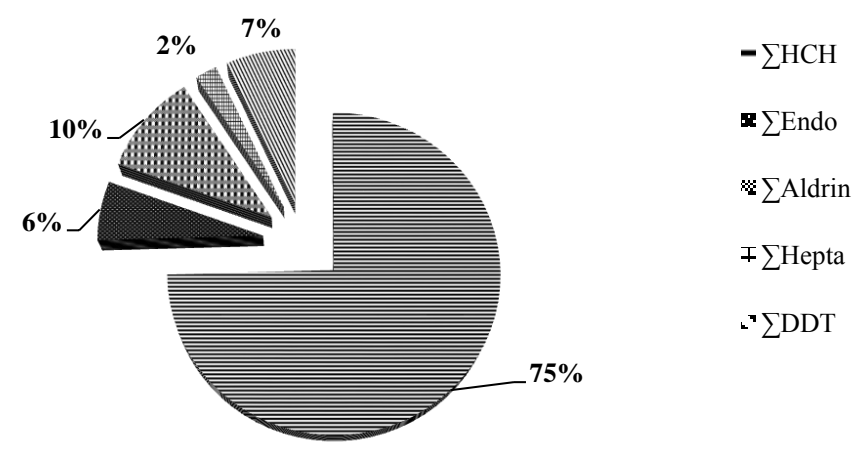

Figure 4. Detection frequency of individual OCPs across UK stretch of Ganga River.

reported in the water matrices from the basin (Rehana et al., 1995; Nayak et al., 1995; Sankararamakrishnan et al., 2005; Semwal and Akolkar, 2006; Malik et al., 2009; Singh et al., 2011). Beside the runoff from agricultural fields, the agricultural practices in the dry bed of the rivers, which are common in India (Hans et al., 1999) also, add pesticides to the river during monsoon. The OCPs levels in UK stretch are shown in Fig. 3. In this stretch concentration of all the targeted OCPs varies from not detected (ND) to $7.07 \mathrm{ng} \mathrm{L}^{-1}$. Water sample from Rishikesh showed the maximum number of OCPs, i.e., 14 out of targeted 16, while the Ganga main river at Haridwar showed presence of least number; only 2 out of 16 were present. The occurrence frequency for the OCPs in this stretch varied from 0 to $100 \%$, as heptachlor and DDT were not detected in any of the samples (detection rate, $0 \%$ ), while $\beta$ - $\mathrm{HCH}$ and $\gamma-\mathrm{HCH}$ were found in all the samples (detection rate, $100 \%$ ). The endosulfan sulfate and endrin were detected in one sample (detection rate, $5 \%$ ) while aldrin, endrin, dieldrin, heptachlor epoxide, $\alpha$-Endo, $\beta$ Endo, DDE and DDD showed $75 \%$ occurrence. The $\sum \mathrm{HCH}$ group was the most predominant in this stretch, accounting $75 \%$ of relative abundance (Fig. 4). The low ratios of $\alpha \mathrm{HCH} / \gamma \mathrm{HCH}(0.15)$ indicate that lindane may be an important source of $\mathrm{HCH}$ in this stretch as technical $\mathrm{HCH}$ sources have high $\alpha \mathrm{HCH} / \gamma \mathrm{HCH}$ (Ridal et al., 1996). The lindane has been used extensively in the Indo-Gangetic plains for agriculture. Wang et al. (2008) reported that the OCPs used in Indo-Gangetic plains could reach the snow of Mount Everest via global circulation and cool deposition. Similar trends of deposition of OCPs in glacier via cold trap have also been reported by Valsechhi et al. (1999) and Kang et al. (2002). Blais et al. (2001) explained that melting glaciers supply up to $97 \%$ of OCPs input while contributes $73 \%$ of input water. In UK zone, the major share comes from melting ice from glaciers, thus high share of HCHs in glacial stream is expected. $\sum$ Endo group's relative abundance was $10 \%$ of the total indicates that this pesticide has limited use for agricultural purposes in this stretch. Very limited farming is done in this part of the Ganga basin, so trace levels of endosulfan residues could find their way into the river water from agricultural application via runoff. The heptachlor group formed $2 \%$ of the total abundance, with no heptachlor been detected in any of the samples. Only heptachlor epoxide was detected in the samples suggested that this pesticide has been used in past in the basin.

The occurrence of OCPs in UP stretch is shown in Fig. 5. The trend of detection rate of OCPs was different in the UP stretch as the detection rate varies from 6-94\% (Fig. 6). All the samples were found to contain one or more pesticides. The minimum number OCPs detected in any sample was 3 , while a maximum of 14 OCPs were present in one of the samples. The $\beta$-Endo OCP was frequently detected in many of the samples in relatively high concentration as the maximum concentration of $\beta$-Endo was $133.10 \mathrm{ng} \mathrm{L}^{-1}$ (Fig. 5). $\sum$ Endo group pesticides contributed the maximum $(75 \%)$, while aldrin, DDT and HCH group contributed 11, 9 and $5 \%$, respectively (Fig. 6). The use of endosulfan is now banned in more than 60 countries but India has been the world's largest producer and consumer of endosulfan with a total use 


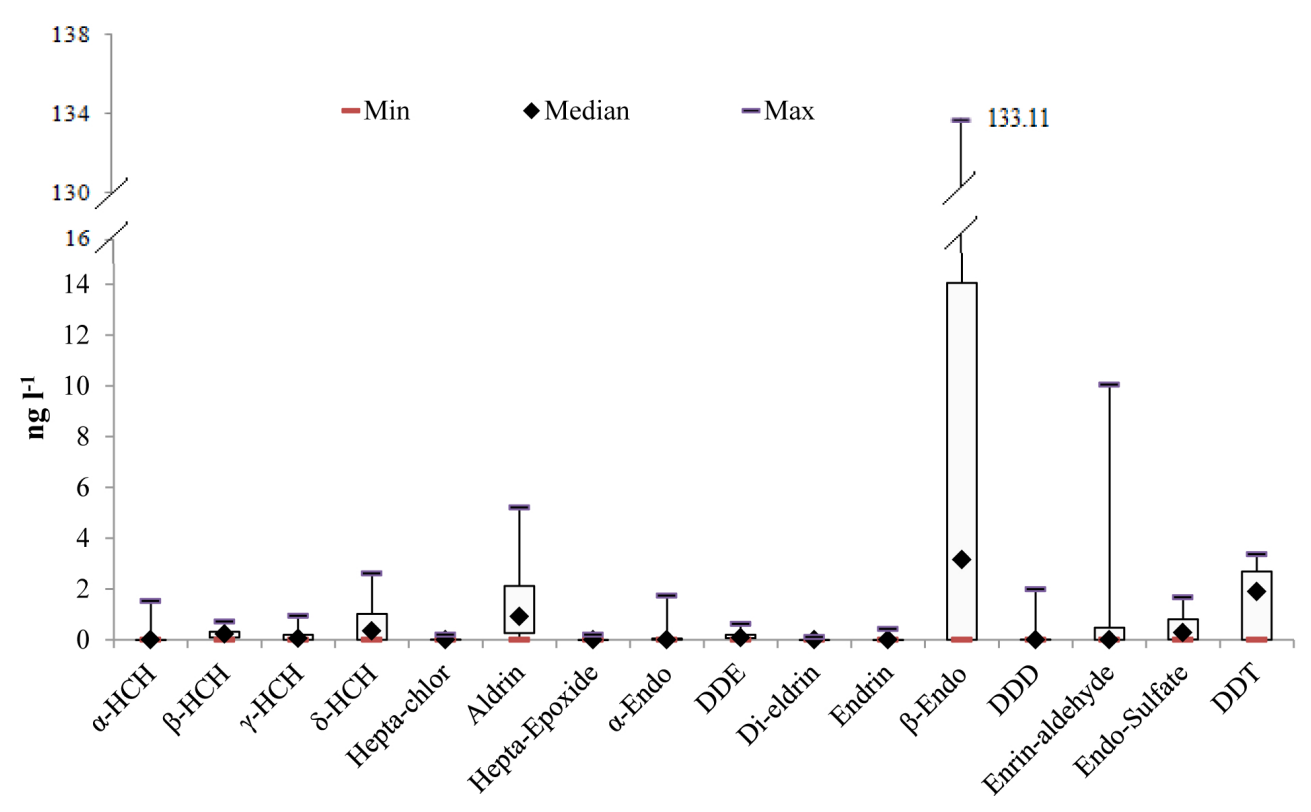

Figure 5. Organochlorine residues $\left(\mathrm{ng} \mathrm{L}^{-1}\right)$ in water matrices of rivers of Uttar Pradesh (UP).
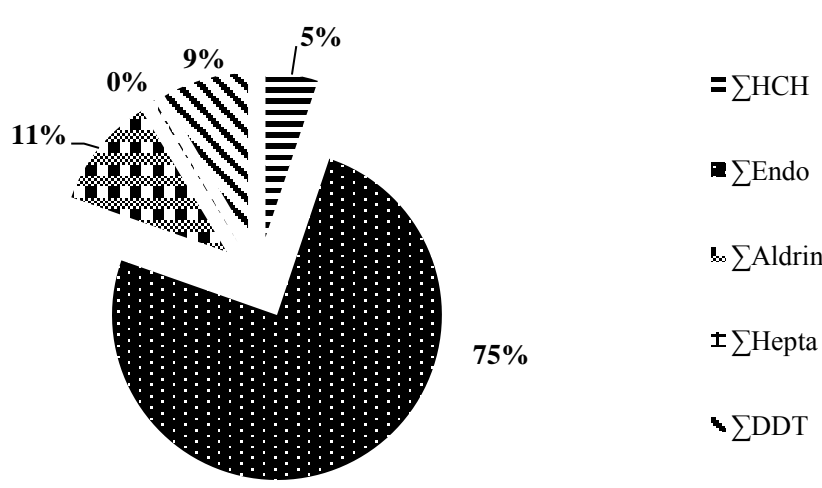

Figure 6. Detection frequency of individual OCPs across UP stretch of Ganga River.

of 113000 tonnes from 1958 to 2000 (NGBRA, 2011). Recently, the supreme court of India has put a temporary ban on agricultural use of endosulfan pesticides (Writ petition 213/2011), but the impacts of this ban could only be noticed after a number of decades. The high concentration of Endo group pesticides is in conformity with its wide use in this area. The endosulfan was most widely used pesticide in Indo-Gangetic plains for agricultural purposes. Most studies suggest that $\alpha$-endosulfan has a faster degradation than $\beta$-endosulfan, and that endosulfan sulfate is much more persistent (INIA, 1999-2004). Similar trends were observed for Endo group pesticides in UP stretch. $\beta$-endosulfan and endosulfan sulfate were more frequently detected in the water samples as compared to $\alpha$-endosulfan. Endosulfan sulfate is the most persistent, but its reported concentrations are lower than its other isomers. It may be due to its lower share $(<1 \%)$ in technical endosulfan. As pesticides are used more sporadically, there are different reports on their occurrences in river Ganga. Higher levels of endosulfan $\left(750 \mathrm{ng} \mathrm{L}^{-1}\right)$ have been previously reported in the Ganges river at Kannauj (Rehana et al., 1996) to the present level of $31.61 \mathrm{ng} \mathrm{L}^{-1}$ but another study has reported absence of endosulfan residues in Ganges at Kanpur (Sankararamakrishnan et al., 2005).

The occurrences of OCPs in Bihar stretch are shown in Fig. 7. The levels of OCPs varied from ND to $38.80 \mathrm{ng} \mathrm{L}^{-1}$ for aldrin in Son river, a major tributary of the river Ganga in Bihar. $\delta$-HCH was not detected in any of the samples, while $\alpha-\mathrm{HCH}$ was present in all the samples (Fig. 7). Frequency of appearance of the OCPs was higher for samples from tributaries of Ganga, than the parent river (Fig. 7). Sample from storm water drain near Ara (Bhojpur) which carried agricultural runoff was containing 15 out of 16 targeted compounds. Sultanganj and downstream to the Bhagalpur city area are located in the most downward stretch of the studied stretches. These stretches were found to contain 15 OCPs. Besides, the average concentration of monitored OCPs continually increased from UK to BR stretch (upstream to downstream) (Fig. 1). It may be due to the continual increase of contribution from the agricultural sector in the downstream stretches. In BR stretch, the occurrence patterns of OCPs were different from the UK and UP stretch. In UK stretch, HCHs group was more frequently detected, while in UP stretch the same was observed in Endo groups. High glacial water in the UK stretch may be a possible reason for this, since the glacial water streams reportedly have higher concentrations ( $1 \mathrm{log}$ ) of HCHs as compared to endosulfan and dieldrin pesticides in Bow lake in Canada (Blais et al., 2001) and Himalayan glaciers (Kang et al., 2009). Bizzotto et al. (2009) 


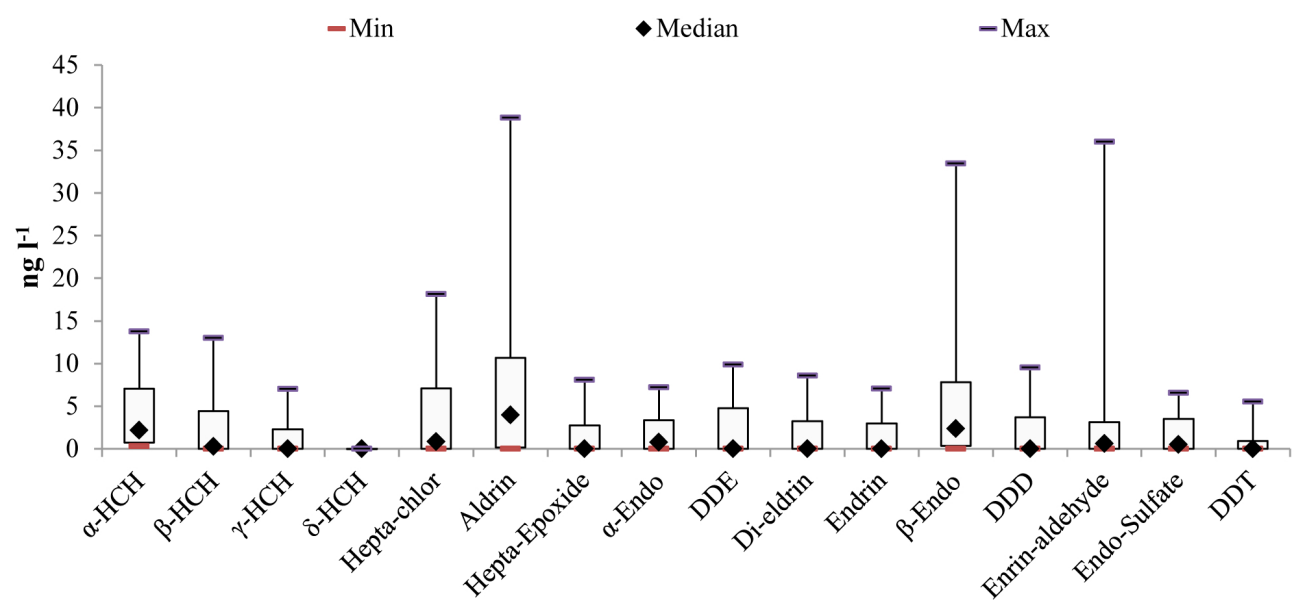

Figure 7. Organochlorine pesticide residues $\left(\mathrm{ng} \mathrm{L}^{-1}\right)$ in water matrices of rivers of Bihar (BR) Area.

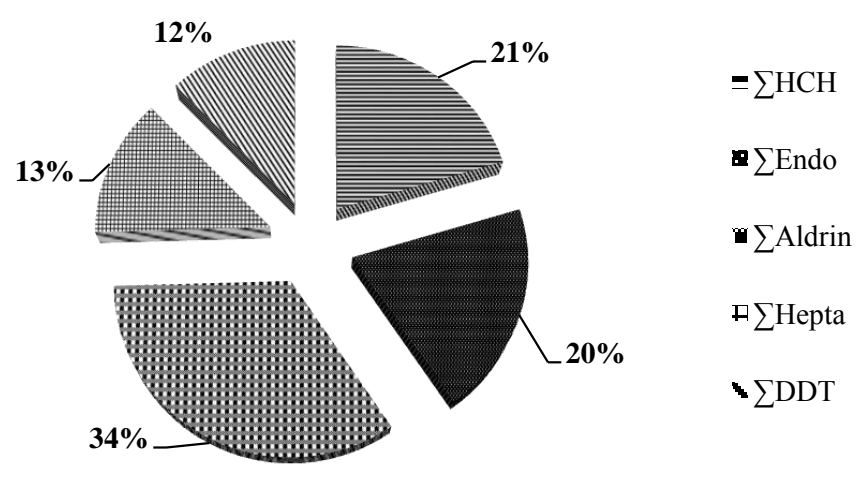

Figure 8. Detection frequency of individual OCPs across BR stretch of Ganga River.

compared the HCHs concentration in glacial and non-glacial streams from Alpine glaciers and found that glacial streams were always having a higher concentration (200-400\%) than non-glacial streams. Thus high frequencies of $\mathrm{HCHs}$ in the mountainous zone of Ganga were on the expected lines. The UP stretch was predominant with the Endosulfan group pesticides in connection with high previous use of this group of pesticides in the Indo-Gangetic plains for agriculture use (NGBRA, 2011). In Bihar stretch, none of these pesticide groups were dominant in occurrences. The maximum detection frequency was for the aldrin group (34\%), followed by HCHs $(21 \%)$, Endo group (20\%), heptachlor group (13\%) and DDTs group (12\%) (Fig. 8). It showed the mixed flow of glacial, domestic, agricultural and industrial discharge to the river. The high concentration of the heptachlor group in this stretch could be because of high previous use of this pesticide in parts of Bihar and West Bengal for termite control. As this stretch of the river receive flow from different river basins, having different agricultural practices and different pesticide uses. So the mixture of all OCPs was expected (Fig. 8). Table 5 presents the relative contamination levels of OCPs in
2011 along with the values reported in the literature. It shows reduction in OCPs levels in the Ganga water.

River waters are highly vulnerable to OCPs contaminations as OCPs once used in river basins are continually released and transported to the rivers and its tributaries via runoff from agricultural and urban areas, discharge from reservoirs and aquifers, and atmospheric deposition. The concentration of OCPs in river water is governed by several factors such as physiochemical properties of the pesticides, its usage, rainfall, and farming practices etc. and thus their concentration may have high spatial and temporal variations. People in the rural areas are directly using Ganges water for potable purposes and thus it is mandatory to compare the OCPs contamination with the regulatory standards. The maximum contaminant levels (MCLs) for pesticides in drinking water in India are described in BIS:10500 (Bureau of Indian Standards, Drinking Water Standard, 2003). The safe limit for pesticides in potable water is described as total pesticides concentration should be less than $1000 \mathrm{ng} \mathrm{L}^{-1}$ for drinking water, however this limit is quite higher compared to the world health organization (WHO) and European Union (EU) limits for potable water $\left(500 \mathrm{n} \mathrm{L}^{-1}\right)$. Variation in total OCPs contamination in individual sample across the monitoring stretches is described in Fig. 9. It's evident from the results (Fig. 9) that Ganges water is safe for potable purposes in terms of OCPs contamination; however other types of pesticides (organophosphates, synthetic pyrethroids etc.) may also be present in river water which was not monitored. As the maximum concentration of total OCPs in individual sample $\left(0.17 \mu \mathrm{gL}^{-1}\right.$, Fig. 9) was within the safe limits and pesticides are also removed during conventional water treatment process (partially to substantially) (Stackelberg et al., 2007) which will further reduce the pesticides levels in finished drinking water. Thus production of water through a water treatment plant is advantageous and minimizes the risk exposed by pesticide contamination as well. Treated water is supplied for potable purposes in most of the cities on the 
Table 5. Comparison of reported OCPs levels in rivers of Ganga Basin to the present study at different locations.

\begin{tabular}{|c|c|c|c|c|c|c|c|c|c|c|c|c|}
\hline \multirow[b]{3}{*}{ River } & \multirow[b]{3}{*}{$\begin{array}{l}\text { Sampling } \\
\text { Site }\end{array}$} & \multicolumn{10}{|c|}{ Compound Reported (ng L ${ }^{-1}$ ) } & \multirow[b]{3}{*}{ *Reference } \\
\hline & & \multicolumn{2}{|c|}{$\sum \mathrm{HCH}$} & \multicolumn{2}{|c|}{$\sum \mathrm{DDT}$} & \multicolumn{2}{|c|}{$\sum$ Endo } & \multicolumn{2}{|c|}{ ¿Aldrin } & \multicolumn{2}{|c|}{$\sum$ Hepta } & \\
\hline & & $\begin{array}{l}\text { Literature } \\
\text { Levels* }\end{array}$ & $\begin{array}{l}\text { Present } \\
\text { Levels } \\
(2011)\end{array}$ & $\begin{array}{l}\text { Literature } \\
\text { Levels* }\end{array}$ & $\begin{array}{l}\text { Present } \\
\text { Levels } \\
(2011)\end{array}$ & $\begin{array}{l}\text { Literature } \\
\text { Levels* }\end{array}$ & $\begin{array}{l}\text { Present } \\
\text { Levels } \\
(2011)\end{array}$ & $\begin{array}{l}\text { Literature } \\
\text { Levels* }\end{array}$ & $\begin{array}{l}\text { Present } \\
\text { Levels } \\
(2011)\end{array}$ & $\begin{array}{l}\text { Literature } \\
\text { Levels* }\end{array}$ & $\begin{array}{l}\text { Present } \\
\text { Levels } \\
(2011)\end{array}$ & \\
\hline \multirow[t]{9}{*}{ Ganga } & Devprayag & ND (2006) & 7.24 & $\begin{array}{l}\text { ND-365 } \\
(2006)\end{array}$ & ND & $\begin{array}{l}\text { ND-66 } \\
(2006)\end{array}$ & ND & $\begin{array}{l}\text { ND-46 } \\
(2006)\end{array}$ & 2.3 & NM & 0.07 & Semwal and Akolkar (2006) \\
\hline & Rishikesh & $\begin{array}{l}6-124 \\
(1992)\end{array}$ & 5.5 & $\begin{array}{l}4-98 \\
(1992)\end{array}$ & 1.01 & & 0.92 & & 1.89 & & 0.32 & ITRC annual report (1992) \\
\hline & Haridwar & $\begin{array}{l}4-153 \\
(1992)\end{array}$ & 5.2 & $\begin{array}{l}2-113 \\
(1992)\end{array}$ & 0.19 & & 0.16 & & 0.12 & & 0.06 & ITRC annual report (1992) \\
\hline & Kannauj & $\begin{array}{l}3010 \\
(1995), \\
8-154 \\
(1992)\end{array}$ & $\begin{array}{l}0.1- \\
1.0\end{array}$ & $\begin{array}{l}7740 \\
(1995), \\
3-150 \\
(1992)\end{array}$ & $\begin{array}{l}0.05- \\
0.12\end{array}$ & $\begin{array}{l}750 \\
(1995)\end{array}$ & $\begin{array}{l}0.8- \\
31.6\end{array}$ & $\begin{array}{l}3340 \\
(1995)\end{array}$ & $\begin{array}{l}1.2- \\
1.3\end{array}$ & NM & $\begin{array}{l}0.14- \\
0.2\end{array}$ & $\begin{array}{l}\text { Rehana et al. (1995) } \\
\text { ITRC annual report (1992) }\end{array}$ \\
\hline & Kanpur & $\begin{array}{l}450 \\
(2005), \\
14-359 \\
(1992)\end{array}$ & $\begin{array}{l}0.1- \\
0.36\end{array}$ & $\begin{array}{l}\text { ND } \\
(2005), \\
8-174 \\
(1992)\end{array}$ & 0.2 & $\begin{array}{l}\text { ND } \\
(2005)\end{array}$ & $\begin{array}{l}9.7- \\
11.6\end{array}$ & $\begin{array}{l}\text { ND } \\
(2005)\end{array}$ & $\begin{array}{l}\text { ND- } \\
1.1\end{array}$ & NM & $\begin{array}{l}\text { ND- } \\
0.08\end{array}$ & $\begin{array}{l}\text { Sankararamakrishnan et al. (2005) } \\
\text { ITRC annual report (1992) }\end{array}$ \\
\hline & Allahabad & $\begin{array}{l}7-270 \\
(1992)\end{array}$ & $\begin{array}{l}1.23- \\
3.5\end{array}$ & $\begin{array}{l}2-136 \\
(1992)\end{array}$ & $\begin{array}{l}0.08- \\
2.21\end{array}$ & & $\begin{array}{l}\text { ND- } \\
0.15\end{array}$ & & $\begin{array}{l}\text { ND- } \\
0.4\end{array}$ & & ND & ITRC annual report (1992) \\
\hline & Varanasi & $\begin{array}{l}9-156 \\
(1992), \\
105- \\
99517 \\
(1995)\end{array}$ & $\begin{array}{l}0.2- \\
0.7\end{array}$ & $\begin{array}{l}3-84 \\
(1992), \\
64- \\
143226 \\
(1995)\end{array}$ & $\begin{array}{l}0.1- \\
1.9\end{array}$ & $\begin{array}{l}83- \\
66516 \\
(1995)\end{array}$ & $\begin{array}{l}\text { ND- } \\
85.4\end{array}$ & NM & $\begin{array}{l}0.5- \\
2.2\end{array}$ & & ND-0.1 & $\begin{array}{l}\text { ITRC annual report (1992) } \\
\text { Nayak et al. (1995) }\end{array}$ \\
\hline & Patna & $\begin{array}{l}11-131 \\
(1992)\end{array}$ & $\begin{array}{l}0.3- \\
5.0\end{array}$ & $\begin{array}{l}5-385 \\
(1992)\end{array}$ & ND & & $\begin{array}{l}\text { ND- } \\
5.03\end{array}$ & & $\begin{array}{l}\text { ND- } \\
1.17\end{array}$ & & ND & ITRC annual report (1992) \\
\hline & Bhagalpur & $\begin{array}{l}\text { ND-74.04 } \\
(2011)\end{array}$ & $\begin{array}{l}12.4- \\
17.6\end{array}$ & $\begin{array}{l}\text { NM } \\
(2011)\end{array}$ & $\begin{array}{l}11.6- \\
12.3\end{array}$ & $\begin{array}{l}\text { ND-208 } \\
(2011)\end{array}$ & $\begin{array}{l}13.8- \\
17.9\end{array}$ & $\begin{array}{l}\text { ND-489 } \\
(2011)\end{array}$ & $\begin{array}{l}8.8- \\
16.4\end{array}$ & $\begin{array}{l}\text { NM } \\
(2011)\end{array}$ & $\begin{array}{l}3.2- \\
11.8\end{array}$ & Singh et al. (2011) \\
\hline Gomti & Lucknow & $\begin{array}{l}\text { ND-507 } \\
(2009)\end{array}$ & 0.72 & $\begin{array}{l}\text { ND-108 } \\
(2009)\end{array}$ & 2.75 & $\begin{array}{l}\text { ND-186 } \\
(2009)\end{array}$ & 1.16 & $\begin{array}{l}\text { ND-82 } \\
(2009)\end{array}$ & 0.6 & $\begin{array}{l}\text { ND-91 } \\
(2009)\end{array}$ & ND & Malik et al. (2009) \\
\hline
\end{tabular}

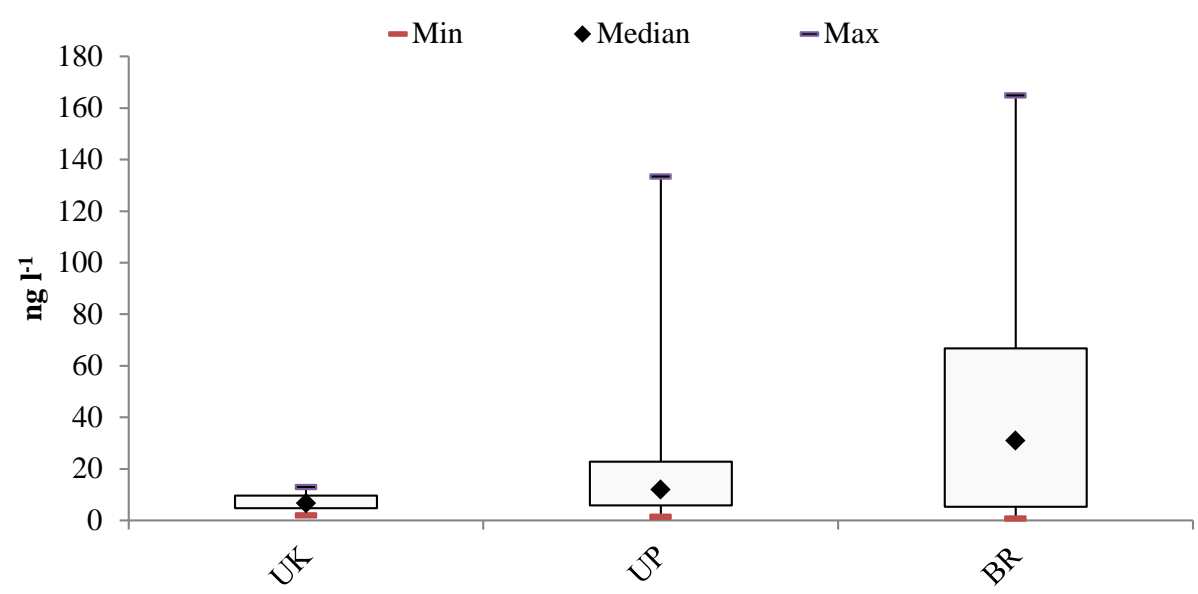

Figure 9. Variation in total OCPs residues in Ganges water (BIS Safe limit $\left.=1000 \mathrm{ng} \mathrm{L}^{-1}\right)$. 
bank of the rivers, but in rural areas it is still consumed without treatment as well. Thus, it is the need of the hour to upgrade the existing water practices and should be moved for treated potable water.

\section{Conclusions}

OCPs, 16 in number were monitored from 82 sampling sites in the Ganga river basin. These included mountainous and the great plains of the Ganga basin. The results revealed that different types of OCPs predominate in different regions depending upon the land use pattern and differential past use of the OCPs for agricultural and public health programme. Since, there is not even a single report on the levels of OCPs representing the entire Ganga stretch; the present findings could be effectively used in understanding the present status of the river. The comparative analysis of present study to the previous reports, showed the decline trend in OCPs contamination in the river water, which is a good sign at environmental and ecological front. The ban on the use of various OCPs has shown a positive sign for river health, but as these compounds are highly lipophillic, thus it becomes quite necessary to monitor these compounds continuously in the river stretch. There is a wide gap in the timeline of the continuous reporting of OCPs levels and thus, it is recommended to frequently monitor the river quality for OCPs contamination with changing land-use pattern, pesticide formulation, climatic conditions and ecological and environmental sense of the society. The decreasing trends in the OCPs contamination levels in Ganges water were also confirmed. The banned or restricted use of OCPs and increasing environmental awareness regarding pesticide application in farmers may be the possible contributor to this declining trend. The maximum total pesticide concentration in individual sample $\left(0.17 \mu \mathrm{gL}^{-1}\right.$, Son river sample from Koilwar) was less than $0.2 \mu \mathrm{gL}^{-1}$ for all the samples against a safe drinking water limit of $0.5 \mu \mathrm{gL}^{-1}$ by European Union (EU) and $1 \mu \mathrm{gL}^{-1}$ of Bureau of Indian Standards (BIS). Lower concentration ( $\mathrm{n} \mathrm{L}^{-1}$ ) of pesticides in rivers indicates the wise use of pesticide in the area but the higher detection rate of endosulfan group pesticide in the UP stretch which receives agricultural runoff from Indo-Gangetic plains are of significant concern. The recent temporary ban on the use of endosulfan for agricultural use by the Supreme Court of India (Writ petition no 213/2011), is a precautionary and an appreciable step towards conserving the water resources from the further POP contamination.

Acknowledgements. Authors are thankful to D. P. Singh, Former Chief Engineer UP Jal Nigam, S. Z. S. Tabish, SE CPWD, S. K. Gupta, N. S. Maurya and Pooja Srivastava for their help during sampling campaigns. One of the authors (Pravin K. Mutiyar) is also thankful to University Grants Commission (UGC), New Delhi (India) for providing financial assistance in the form of Junior Research Fellowship (JRF) to conduct this work.
Edited by: J. Verberk

\section{References}

APHA, AWWA: Standard Methods for Examination of Water and Wastewater Investigations, APHA, AWWA, Washington, DC, 1998.

Bizzotto, E., Villa, S., Vaj, C., and Vighi, M.: Comparison of glacial and non-glacial-fed streams to evaluate the loading of persistent organic pollutants through seasonal snow/ice melt, Chemosphere, 74, 924-930, 2009.

Blais, J., Schindler, K., Muir, D., Donald, D., Sharp, M., Lafreniere, M., Braekevelt, E., and Strachan, W. M. J.: Melting glaciers dominate sources of persistent organochlorines to subalpine Bow Lake in Banff National Park, Canada, Ambio, 30, 410-415, 2001.

Bureau of Indian Standard (BIS): BIS10500-1991, Indian Standard Drinking Water-Specification, 2003.

CPCB: Ganga water quality trends, Monitoring of Indian Aquatic Resources, MINARS/31/2009-2010 available at: http://cpcb.nic.in/upload/NewItems/NewItem_168_ CPCB-Ganga_Trend\%20Report-Final.pdf, 2009.

CPCB report: Status of sewage treatment plants in Ganga basin, Central Pollution Control Board, available at: http://www.cpcb. nic.in/newitems/8.pdf, 2009.

Duda, A. M.: Addressing non-point sources of water pollution must become an international priority, Water Sci. Technol., 28, 1-11, 1993.

Hans, R. K., Farooq, M., Suresh Babu, G., Srivastava, S. P., Joshi, P. C., and Viswanathan, P. N.: Agricultural produce in the dry bed of the River Ganga in Kanpur, India - a new source of pesticide contamination in human diets, Food Chem. Toxicol., 37, 847852, 1999.

Holvoet, K. M. A., Seuntjens, P., and Vanrolleghem, P. A.: Monitoring and modeling pesticide fate in surface waters at the catchment scale, Ecol. Modell., 209, 53-64, 2007.

INIA: Instituto Nacional de Investigación y Tecnología Agraria y Alimentaria (I.N.I.A.) including addenda available at: http://chm.pops.int/Convention/POPsReviewCommittee/ Meetings/POPRC4/Convention/tabid/359/Default.aspx, 19992004.

ITRC: Industrial Toxicological Research Centre, Lucknow, 6th Annual Progress Report (July 1991-June 1992), Measurements on Ganga water quality - Heavy metal and Pesticides, http://www. itrc.org, 1992.

Jain, C. K.: Hydro-chemical study of a mountainous watershed: the Ganga, India, Water Res. 36, 1262-1274, 2002.

Kang, J. H., Choi, S. D., Park, H., Baek, S. Y., Hong, S., and Chang, Y. S.: Atmospheric deposition of persistent organic pollutants to the East Rongbuk Glacier in the Himalayas, Sci. Total Environ., 408, 57-63, 2009.

Kang, S. C., Mayewski, P. A., Qin, D. H., Yan, Y., Hou, S., Zhang, D., Ren, J., and Kruetz, K.: Glaciochemical records from a Mt. Everest ice core: relationship to atmospheric circulation over Asia, Atmos. Environ., 36, 3351-3361, 2002.

Kreuger, J.: Pesticides in stream water within an agricultural catchment in southern Sweden, 1990-1996, Sci. Total Environ., 216, 227-251, 1998.

Kumar, A., Bisth, B. S., Joshi, V. D., Singh, A. K., and Talwar, A.: Physical, Chemical and Bacteriological Study of Water from 
Rivers of Uttarakhand, J. Hum. Ecol., 32, 169-173, 2010.

Malik, A., Ojha, P., and Singh, K. P.: Levels and distribution of persistent organochlorine pesticide residues in water and sediments of Gomti River (India) - a tributary of the Ganges River, Environ. Monit. Assess., 148, 421-435, 2009.

Mutiyar, P. K., Mittal, A. K., and Pekdeger, A.: Status of organochlorine pesticides in the drinking water well-field located in the Delhi region of the flood plains of river Yamuna, Drink. Water Eng. Sci., 4, 51-60, doi:10.5194/dwes-4-51-2011, 2011.

Mutiyar, P. K. and Mittal, A. K.: Occurrences and fate of an antibiotic amoxicillin in extended aeration-based sewage treatment plant in Delhi, India: a case study of emerging pollutant, Desalin. Water Treat., doi:10.1080/19443994.2013.770199, in press, 2013.

Nayak, A. K., Raha, R., and Das, A. K.: Organochlorine pesticide residues in middle stream of the Ganga river, India, Bull. Environ. Contam. Toxicol., 54, 68-75, 1995.

NGBRA: National Ganga River Basin Authority (NGRBA), Draft, Environmental and Social Management Framework (ESMF), Volume I - Environmental and Social Analysis, 2011, available at: http://moef.nic.in/downloads/public-information/Draft\% 20ESA\%20Volume\%20I.pdf, 2011.

Oliver, D. P., Kookana, R. S., Anderson, J. S., Cox, J. W., Fleming, N., Waller, N., and Smith, L.: Off-site transport of pesticides from two horticultural land uses in the Mt. Lofty Ranges, South Australia, Agric. Water Manage., 106, 60-69, 2012.

Rehana, Z., Malik, A., and Ahmad, M.: Mutagenic activity of the Ganges water with special reference to the pesticide pollution in the river between Kachla to Kannauj (U.P.), India, Mutat. Res., 343, 137-144, 1995.

Ridal, J. J., Kerman, B., Durham, L., and Fox, M. E.: Seasonality of air-water fluxes of hexachlorocyclohexanes in Lake Ontario, Environ. Sci. Technol., 30, 852-858, 1996.

Sankararamakrishnan, N., Kumar Sharma, A., and Sanghi, R.: Organochlorine and organophosphorous pesticide residues in ground water and surface waters of Kanpur, Uttar Pradesh, India, Environ. Int., 31, 113-120, 2005.
Schulz, R.: Comparison of spray drift- and runoff-related input of azinphos-methyl and endosulfan from fruit orchards into the Lourens River, South Africa, Chemosphere, 45, 543-551, 2001a.

Schulz, R.: Rainfall-induced sediment and pesticide input from orchards into the Lourens River, Western Cape, South Africa: Importance of a single event, Water Res., 35, 1869-1876, $2001 \mathrm{~b}$.

Semwal, N. and Akolkar, P.: Water quality assessment of sacred Himalayan rivers of Uttaranchal, Curr. Sci. India, 91, 486-496, 2006.

Singh, L., Choudhary, S. K., and Singh, P. K.: Organochlorine and Organophosphorous pesticides residues in Water of River Ganga at Bhagalpur, Bihar, India, Int. J. Res. Chem. Environ., 1, 77-84, 2011.

Stackelberg, P. E., Gibs, J., Furlong, E. T., Meyer, M. T., Zaugg, S. D., and Lippincott, R. L.: Efficiency of conventional drinkingwater-treatment processes in removal of pharmaceuticals and other organic compounds, Sci. Total Environ., 377, 255-272, 2007.

Valsecchi, S., Smiraglia, C., Tartari, G., and Polesello, S.: Chemical composition of Monsoon deposition in the Everest region, Sci. Total Environ., 226, 187-199, 1999.

Varca, L. M.: Pesticide residues in surface waters of PagsanjanLumban catchment of Laguna de Bay, Agric. Water Manage., 106, 35-41, 2012.

Wang, X., Xu, B., Kang, S., Cong, Z., and Yao, T.: The historical residue trends of DDT, hexachlorocyclohexanes and polycyclic aromatic hydrocarbons in an ice core from Mt. Everest, central Himalayas, China, Atmos. Environ., 42, 6699-6709, 2008.

Writ Petition 213/2011: Supreme Court of India, Record of Proceeding, available at: http://supremecourtofindia.nic.in/outtoday/ wc21311p.pdf, 2011. 